\title{
RE-IGNITING CRITICAL RACE IN CANADIAN LEGAL SPACES: INTRODUCTION TO THE SPECIAL SYMPOSIUM ISSUE OF CONTEMPORARY ACCOUNTS OF RACIALIZATION IN CANADA
}

\author{
Shanthi Elizabeth Senthe \\ Sujith Xavier*
}

\section{INTRODUCTION}

Osgoode Hall Law School, York University's Challenging Conventions! Speaker Series organized ReIgniting Critical Race: A Symposium on Contemporary Accounts of Racialization in Canada on November 2, 2012. The symposium sought to explore critical race theory ${ }^{1}$ and its praxis within the Canadian legal academy by inviting emerging scholars and practitioners to engage with the scholarship of Professor Patricia Williams. Williams is a pioneer in using narrative ${ }^{2}$ as method in legal scholarship under the umbrella of critical race theory. ${ }^{3}$ Broadly, the critical race theory movement is comprised of academics, students and activists interested in "studying and transforming the relationship among race, racism and power". ${ }^{4}$ Picking up from the American Civil Rights movement's concerns of racial equality and equity, critical race theory situates these concerns within broader interdisciplinary perspectives that include economics, history, politics and other disciplines. The aim of activists and scholars working

* Shanthi Elizabeth Senthe is an Assistant Professor at the Faculty of Law, Thompson Rivers University. Shanthi teaches business associations, remedies, corporate governance and secured transactions. Sujith Xavier is an Assistant Professor, Faculty of Law University of Windsor. Sujith teaches access to justice, administrative law and international criminal law. The authors would like to extend their gratitude to Igor Gontcharov, Ruth Buchanan, Sonia Lawrence \& Peer Zumbansen for their invaluable assistance in organizing the symposium. We want to thank Osgoode Hall Law School in making this event possible. We like to extend a special thanks to Jacqueline Hardy and Emily Quail for editorial assistance and to the conference participants. We are indebted to the Windsor Yearbook of Access to Justice's Editor and Chief, Dr. Laverne Jacobs and Windsor Yearbook of Access to Justice Coordinator, Vidya Balachandar for guidance and editorial assistance. All errors are ours.

1 Richard Delgado \& Jean Stefancic, Critical Race Theory: An Introduction (New York: New York University Press, 2012) pp 1-16; Kimberle Williams Crenshaw, "Twenty Years of Critical Race Theory: Looking Back to Move Forward" (2011) 43:5 Conn L Rev 1253.

2 In an interview with James Hackney in 2012, Williams states the following: "My writing has sometimes been dismissed as just storytelling and I don't think it's an entirely correct label. I do use lots of literary devices and I have employed the first person even in law reviews, but I've done it for very specific effect and in a very calculated way. People sometimes forget that a lot of my writing is not in the first person; that it's not stream of consciousness; or that I would never do it in a courtroom or a brief. [...] What happens when you use the first person in a law review that never uses the first person? It's like using polar bears. It's play, and it's intended to make you think about the context and ask what new information this might be imparting. If you write exclusively for any and all purposes in the first person it does risk becoming solipsistic; but is an unexpected forum it be startling in a good way". James Hackney, Legal Intellectuals in Conversation: Reflection on the Construction of Contemporary American Legal Theory (New York: New York University Press, 2012) at 121.

3 Delgado \& Stefancic, supra note 1 at 1-16; Kimberle Williams Crenshaw, "Twenty Years of Critical Race Theory: Looking Back to Move Forward" (2011) 43:5 Conn L Rev 1253

$4 \quad$ Delgado \& Stefancic, supra note 1 at 3. 
under the rubric of critical race theory is to question the "very foundations of the liberal order" and the continued preservation of white supremacy and/or racial hierarchies. ${ }^{5}$

In Canada, critical race theory has evolved slowly and incorporates diverse perspectives. Drawing inspiration from American scholars, Canadian critical race theorists have sought to explore the role of law and the role of courts in maintaining racial segregation. ${ }^{6}$ Currently, in Canada, there is a powerful, albeit small body of literature that seeks to connect the relationship between race, law and power in a settler colonial context and beyond. ${ }^{7}$

As the symposium conveners ${ }^{8}$ and graduate students at Osgoode Hall Law School, we had two underlying purposes for the symposium. First, we envisioned an interdisciplinary scholarly engagement on race and law, and second, we wanted to elicit contemporary reflections on Williams' influential text. The papers included in this special symposium issue of the Windsor Yearbook of Access to Justice are the results of this project. The symposium was a celebration of Professor Williams' 1993 "Alchemy of Race and Rights: Diary of a Law Professor" (Alchemy). In this text, Williams cogently chronicles her experience as a Black law professor in recognized institutions in the United States. This book has inspired many students, law professors and continues to capture the imagination of first year and upper year law students. ${ }^{10}$ We thus, used the text as a springboard to potentially re-ignite discussions on critical race theory in Canada.

In what follows, we will first set out the rationale for this project, why we chose the title of reigniting critical race theory and lay out the theoretical landscape that inspired the formulation of the central tenets of the symposium. Then, we will provide a brief overview of the different scholarly papers and personal reflections included in this special issue.

$5 \quad$ Ibid.

6 Adrian A Smith, Racialized In Justice: The Political and Legal Regulation of Migrant Agricultural Workers in Canada [Windsor Yearbook of Access to Justice, Forthcoming in this symposium issue] at p 15; James W St G Walker, 'Race', Rights and the Law in the Supreme Court of Canada: Historical Case Studies (Toronto: Osgoode Society for Canadian Legal History \& Wilfrid Laurier University Press, 1997).

7 Constance Backhouse, Colour-Coded: A Legal History of Racism in Canada: 1900- 1950 (Toronto: University of Toronto Press, 1999); Barrington Walker, Race On Trial: Black Defendants In Ontario's Criminal Courts, $1858-1958$ (Toronto: University of Toronto Press, 2010); David M Tanovich, "The Charter of Whiteness: Twenty-Five Years of Maintaining Racial Injustice in the Canadian Criminal Justice System” (2008) 40 SCLR (2d) 655; Glen Sean Coulthard, Red Skin White Masks: Rejecting The Colonial Politics of Recognition (Minneapolis: University of Minnesota Press, 2014).

8 Igor Gontcharov, B.A. (Hon.), M.A., M.A., LL.M., Ph.D. Candidate, Senior Fellow, Critical Research Laboratory in Law and Society, Osgoode Hall Law School; Shanthi Elizabeth Senthe, Assistant Professor, Thompson Rivers University Law School \&; Sujith Xavier, Assistant Professor Faculty of Law University of Windsor.

9 Patricia J. Williams, The Alchemy of Race and Rights (London: Virgo Press, 1993).

10 Williams' Alchemy is one of the texts assigned in Access to Justice, a mandatory first year law school course taught by Sujith Xavier. 


\section{THE CONFERENCE: RE-IGNITING CRITICAL RACE THEORY IN CANADA?}

Taking our cue from Williams, and the recently celebrated 20-year anniversary of the critical race theory movement, ${ }^{11}$ we, as the symposium conveners, chose to reflect on the Canadian perspectives of critical race theory and law. Williams links her journey to the theoretical construction of the law, and simultaneously edifies the intersectional nature of racialization, class, gender, and sexuality in Alchemy. ${ }^{12}$ Two decades later, her narrative as a law professor, albeit a personal one, is possibly every racialized person's experience in legal academia. ${ }^{13}$ The static nature of contemporary legal education has created simmering undercurrents within student admission policies, curriculum design and delivery, training future lawyers, faculty recruitment and retention. It is in this spirit that the conveners of the symposium considered critical race theory as an emancipatory ideal to be employed in legal education and scholarship.

The Davies LLP advertisement in the Osgoode Hall Law School student paper Obiter Dicta was one of the central motivating factors for our symposium. ${ }^{14}$ The law firm, a frequent recruiter of law students from various law schools in Canada, included an advertisement in the student newspaper that suggested that their employees work hard and "play" hard. In doing so, it described their employees as "slavies", playing off the law firm's trademarked name and the age old, but deeply problematic and racist reference to law students as slaves. These sentiments were reinforced by the advertisement's offensive usage of the term slavies (which was subsequently removed by the law firm with an apology). The discussion about the advertisement, both inside the classroom and in the hallways, was no doubt difficult. The challenging nature of these conversations, in a polemic fashion, lead us to start from the premise that there is a remarkable absence of informed critical race theory in Canadian law schools. The speculative rationale for this absence is further buttressed by various other factors that manifested during these difficult student conversations, including law students' unease with critical race theory as a standalone course.

Another rationale for organizing the symposium is to highlight and counter the reactions to critical race theory by students and law professors in the academy. This can often be summarized through such questions, such as "what does race have to do with this case"15 or "are there any racial implications in the jurisprudence?" In explicitly setting out the connections between critical race theory and law, we wanted our students to create the necessary but albeit hidden linkages between race, racism and power and law and the legal community. Moreover, we wanted our students, as future lawyers, to be able to

11 The 20-year anniversary of Critical Race Theory was celebrated at a speaker series held by the University of Iowa, College of Law on April 2-4, 2009. Papers from the speaker series appear in CRT 20: Honoring Our Past, Charting Our Future (2009) 94:5 Iowa L Rev.

12 Williams, supra note 9 at 1-14.

13 The authors contend that race as a social marker can be replaced with other signifiers such as gender, sexual orientation or ability.

14 For more details, please see Omar Ha-Redeye, “These Days the Slaves Fight Back” (24 January 2012) online: Law is Cool <http://lawiscool.com/2012/01/24/these-days-the-slaves-fight-back/>.

15 A question that was recently raised in Sujith Xavier's Judicial Review (Transnational Perspectives) when discussing Mavis Baker's judicial review of the Minister of Citizenship and Immigration's denial of her Humanitarian and Compassionate grounds application; Baker v Canada (Minister of Citizenship and Immigration), [1999] 2 SCR 817. 
deploy legal arguments that takes account of race, racism and power in their future lived experience as advocates before various institutional settings.

As graduate students and now tenure track law professors, we noticed that legal pedagogy often omits a critical race approach in curriculum design and delivery. In our time in graduate institutions with teaching responsibilities, such as at Osgoode Hall Law School, the first year mandatory course for law students, entitled Ethical Lawyering in a Global Community, offered first year law students with a brief foray into alternative perspectives such as critical race theory by assigning non-traditional readings. ${ }^{16}$ The readings include Professor Constance Backhouse's "Gender and Race in the Construction of the Legal Professionalism" "17 and Professor David Wilkins" "Beyond Bleached Out Professionalism". ${ }^{18}$ This inclusion and acknowledgment of race compares faintly with the stark reality of the racialized lived experience in the legal community, especially when contrasted with law firm hiring practices based on 'fit' or other socializing forces in law schools. ${ }^{19}$

The remarkable 'absence' of critical race theory in law schools' first year curriculum, however, can also be contrasted with the rich Canadian jurisprudence and interdisciplinary scholarship on race and the law. $^{20}$ There are numerous cases that touch on the issue of race in contemporary Canadian criminal law, constitutional law, and administrative law or dare we say contracts! $!^{21}$ As such, we sought to revive this particular 'overlooked' approach and examine how 'race' is shaped and applied in contemporary legal spaces.

We not only wanted to change the conversation, but we also wanted to add richness and depth to contemporary legal issues in the conversations unfolding in the halls of our legal communities and beyond. Students emerging from their respective law schools with newly minted law degrees will go on to represent clients with legal issues where race, racism and power may be significant factors embedded within the claims. By re-igniting critical race, we wanted to ensure that students would have the necessary tools in identifying and articulating the relationship between law and race. The pedagogical necessity to connect race and law is even more relevant in our contemporary reality, given the changing nature of governance in a post 9/11 global era. It is for these reasons we were compelled to suggest a reignition of interest in the critical race theory conversations in Canada and to re-infuse the institutional structure with a new mode of engagement.

16 Sujith Xavier was a teaching assistant in Ethical Lawyering in a Global Context from 2009 to 2012.

17 Constance Backhouse, "Gender and Race in the Construction of 'Legal Professionalism': Historical Perspectives" (Paper delivered at the First Colloquium on the Legal Profession, October 2003), online: Law Society of Upper Canada $<$ http://www.lsuc.on.ca/media/constance_backhouse_gender_and_race.pdf $>$.

18 David B Wilkins, "Beyond "Bleached Out" Professionalism:- Defining Professional Responsibility for Real Professionals" in Deborah L Rhode, ed, Ethics in Practice: Lawyers? Roles, Responsibilities, and Regulation (Oxford: Oxford University Press, 2000).

19 Law Society of Upper Canada, Developing Strategies for Change: Addressing Challenges Faced by Racialized Licensees (October 2014), online: Law Society of Upper Canada $<$ http://www.lsuc.on.ca/uploadedFiles/Equity_and_Diversity/Members/Challenges_for_Racialized_Licensees/Consultation_Paper_Offical\%2812\% 29.pdf $>$.

20 See e.g. $R v S(R D)$, [1997] 3 SCR 484; $R v$ Grant, 2009 SCC 32, [2009] 2 SCR 353; Pieters v Peel Law Assn., 2013 ONCA 396, 228 ACWS (3d) 204; Sherene Razack, ed, Race, Space and the Law: Unmapping a White Settler Society (Toronto: Between the Lines, 2002); Bonita Lawrence \& Enakshi Dua. "Decolonizing Anti-Racism" (2005) 32:4 Social Justice: A Journal of Crime, Conflict and World Order 120.

21 Adrian Smith, "Racialized In Justice", supra note 6. 
The history of critical race theory is imbricated in the rich theoretical debates about the very nature of law. These debates can be traced back to legal formalism of the $19^{\text {th }} / 20^{\text {th }}$ century and the realist criticisms to the formalist approach to law in the United States. ${ }^{22}$ The legal realist movement which started as an empirical response to law's formalism lead the way to multiple and diverse theoretical debates in challenging liberal legalism in the 1970s and 1980s through the critical study of law scholarship (or critical legal studies) and feminism in the United States. ${ }^{23}$ These challenges encouraged and inspired the outgrowth of critical race theory, as a breakaway faction from critical legal studies and feminism. ${ }^{24}$

As we move into the 1990's and early 2000's, we see that certain fields of law were either left bankrupt of critical race theory, or these fields were co-opted, reformulated and reimagined. ${ }^{25}$ Canadian refugee and immigration law, a dominant cite of racial profiling, is one of these legal subfields that can be used to demonstrate some of these effects. The effects of globalization ${ }^{26}$ and the war on terror somewhat diluted the hard fought inroads to equality of the earlier access to justice era as encapsulated with immigration and refugee protection regime. ${ }^{27}$ The regime regulates migrants, refugees and visitors as they enter the borders of Canada. In particular, the refugee protection provisions arguably seek to protect those fleeing persecution based on a number of grounds such as race, ethnicity, sexual orientation and gender. ${ }^{28}$ But there has been a massive shift in this thinking recently. To illustrate, the war on terror precipitated by the terrorist attacks on the Twin Towers in New York City, prompted the Canadian government to amend the Immigration and Refuge Protection Act (IRPA). ${ }^{29}$ In this new version of the act, the Federal government sought to declare inadmissible those alleged to have terrorist links, even if they were accepted as bona fide refugees. ${ }^{30}$ Much more fundamentally, the recent amendments limit the disclosure of secret evidence collected by Canadian administrative agencies under the auspices of national security concerns. ${ }^{31}$ Canadian courts continue to grapple with this particular regime as the very nature of due process rights and fundamental freedoms are at stake. These protected guarantees are at the pinnacle of our democratic community.

In most instances, the Canadian Supreme Court has found that the Canadian Federal government's action against those suspected of international terrorism is fraught with both procedural and substantive irregularities. For example, in Charkaoui v Canada, the Supreme Court declared the duty of procedural fairness had not been afforded to Adil Charkaoui because the government did not disclose all of the relevant evidence. ${ }^{32}$ What is undeniable is the manner in which the laws are used as blunt instruments to

Joseph Singer, "Legal realism Now" (1998) 76:2 Cal L Rev 465 at 474.

23 Delgado \& Stefancic, supra note 1at 1-16.

24 In fact, Patricia Williams, along with Richard Delgado and others were the pioneers of this particular field; James Hackney, Legal Intellectuals in Conversation: Reflection on the Construction of Contemporary American Legal Theory (New York: New York University Press, 2012) at 113.

25 See e.g. $R v$ Grant, 2009 SCC 32, [2009] 2 SCR 353.

26 Manfred Steger, Globalization: A Very Short Introduction (Oxford: Oxford University Press, 2009).

27 Roderick Macdonald, “Access to Justice and Law Reform" (1990) 10 Windsor YB Access Just 287.

28 Convention relating to the Status of Refugees, 29 July 1951, 189 UNTS 150 (entered into force 22 April 1954).

29 Immigration and Refugee Protection Act, SC 2001, c 27.

30 Charkaoui v Canada (Citizenship and Immigration), 2008 SCC 38, [2008] 2 SCR 326.

31 See e.g. ibid; Almrei v Canada (Attorney General), [2003] OJ No 5198; Canada (Citizenship and Immigration) v Harkat 2014 SCC 37

32 Charkaoui, supra note 30. 
perpetuate inequality of treatment of those that are racialized. Moreover, in June 2015, the Canadian Parliament enacted the Anti-terrorism Act, 2015 (Bill C-51). The Act is described as a controversial measure in combatting terrorism. Prior to its enactment, this legislation was heavily criticized for its broad and disproportionate application on Indigenous People and immigrant communities, especially the Muslim communities. ${ }^{33}$ Critics suggest a number of different ways that this legislation will impact these already marginalized communities through its expansive surveillance power, such as increased racial profiling (especially within Muslim communities) ${ }^{34}$ and to criminalize legal dissent and protest. ${ }^{35}$ It has also been described as creating a culture of fear within a democratic society ${ }^{36}$ The continual battle for equality now seems illusory. What is clear from this case and the recent legislation is that the individuals alleged to have terrorist links are racially profiled based on their physical appearance, country of origin status and their religious beliefs. ${ }^{37}$ The national security jurisprudence encapsulated within Canadian immigration and refugee law is illustrative indicator of the absence of critical race theory in law.

The above example questions whether Canadian critical race theory is at a standstill, or whether this academic stagnation is solely a result of pedagogical shifts in legal education as representative of the turn to conservatism of our time. It is undisputed that critical race theory (and critical legal studies) gave way to some of the most powerful and insightful interventions that sought to highlight the political, racist and colonial nature of the many faces of law.

Our Re-Igniting Critical Race symposium thus sought to address the definitional contours of critical race theory, the distinctions between American and Canadian approaches, as well as pragmatic constraints and challenges. Further, the articulation of this broad discourse endogenously created critical frames used by legal scholars, which are continually redefined, augmented and redeployed. This conversation therefore is only a starting point and a point of departure to critically engage in selfreflection. This special issue is a continuation of the conversation we started in November 2012.

This Special Issue of the Windsor Yearbook of Access to Justice features three essays, which collectively interrogate the law in modern times through an analysis of current Canadian legal issues. Two very divergent personal reflections are also included in this issue, which specifically consider the common undercurrents rippling through Critical Race Theory praxis. The idea to include these personal narratives on the intersection of critical race theory was an organic reaction to embrace an element of the 'narrative' and in response to some of our personal and professional experiences as law teachers. This

33 See Desmond Cole, "Taking Action Against Bill C-51", The Walrus (March 16 2015) online: <http://thewalrus.ca/taking-action-against-bill-c-51/> See also Daniel Tseghay, "Bill C-51, security certificates, and their shared racist roots" Rabble Blogs (April 18 2015) online: <http://rabble.ca/blogs/bloggers/daniel-tseghay/2015/04/bill-c-51security-certificates-and-their-shared-racist-roots>.

34 See Amira Elghawaby, "Canadian Muslims Can Expect More Discrimination Under Bill C-51", The Huffington Post (March 16 2015) online: <http://www.huffingtonpost.ca/amira-elghawaby/discrimination-against-

muslims_b_7071952.html>. See also Yavar Hameed and Baljit Nagra "Bill C-51 will worsen racial profiling of Muslim Canadians", Richochet (March 27 2015) online: <https://ricochet.media/en/364/bill-c-51-will-worsen-racial-profiling-ofmuslim-canadians>.

35 See Cole, supra note 33.

36 See Hameed and Nagra, supra note 34.

37 Commission of Inquiry into the Actions of Canadian Officials in Relation to Maher Arar (Ottawa: Public Works and Government Services Canada, 2006). 
Special Issue also includes two special reflections by Professor Williams and Professor Sonia Lawrence based on their comments during the symposium.

\section{SYMPOSIUM PAPERS AND REFLECTIONS}

The articles in this Special Issue draw on a multitude of complex issues from Canadian jurisprudence employing a critical race approach in three different registers: indigeneity, settler colonialism and migration; labour and migrant workers; and human rights. Critical race theory has typically and historically provided scholars a particular methodology to deconstruct normative claims in law. ${ }^{38}$ Carol A. Aylward, like many critical race scholars, poignantly suggests scholars of colour were instinctively drawn towards the critical legal studies movement due to its promise of undoing the legal constructs of law manifested in oppressive institutionalized inequality. ${ }^{39}$ The critical legal studies movement, however, failed to acknowledge race as a primary factor embedded within this paradigm. ${ }^{40}$ The papers and reflections in this special issue prioritize race as a factor in law's normativity.

This Special Issue starts with an article by Professor Amar Bhatia, who skillfully connects rich indigenous history to immigration and migration policy in Canada. Not only is this piece a significant contribution to Canadian history, but it deconstructs our perception of true Canadian identity in the wake of settler colonial, post-colonial, multicultural, immigration and migration policies. By highlighting specific debates of indegeneity and decolonization within an anti-racist approach, Bhatia seeks to redefine identity politics within a settler-colonial context. Bhatia's article complements Canadian critical race scholarship by seeking to connect anti-racist and critical race work in immigration law and studies with insights from Aboriginal law and treaty relations. Ultimately, this article aims to contribute to discussions about transnational migration in a settler colonial context that is informed by Indigenous laws and legal traditions. It does so by exploring different academic debates, stories, and narratives about the right to be here and what it means for those with precarious status to assert that 'we are all here to stay'.

In a similar vein, Professor Adrian Smith artfully expands on identity politics through the application of critical race theory to labour exploitation with respect to Canada's policy on temporary migration. Smith's thought-provoking piece suggests how legalized racism is fueled by the interwoven links of racialization within labour migration, which is further complicated by the stratification of class. The tridimensional analysis in this article sets out the power dynamics in categorizing racialized immigrants within the migrant labour discourse. Smith persuasively suggests that the hyper-exploitation of temporary migrant workers in Canada is systemic and rooted in racialized categorization, thereby rejecting notions of a post-racial era promulgated by liberal academics. In fact, Smith demonstrates how purported 'objective' policies do in fact have adverse effects on people of colour. Furthermore, he examines the intersectionality of gender dynamics within this paradigm. In thinking about temporary labour migration regimes, he argues:

38 Duncan Kennedy, "The Critique of Rights" in Wendy Brown \& Janet Halley, eds, Left LegalismLeft Critique (Durham, NC: Duke University Press, 2002) at 184.

39 Carol A Aylward, Canadian Critical Race Theory: Racism and the Law (Halifax: Fernwood Publishing, 1999) at 27.

$40 \quad$ Ibid at 27. 
gendered disparities in social reproduction are reproduced on a global scale. In this way, global apartheid characterizes gendered structural inequalities in addition to racialized ones. It therefore seems farcical to discuss the pacification of migrant labour without also accounting for social reproduction, for instance in terms of distributional effects across families or households of migrant workers. ${ }^{41}$

Smith uses a novel framework to deconstruct how "racialized laboring bodies" are regulated and governed through Canadian immigration and labour policies.

Professor Faisal Bhabha articulates a similar sentiment in his article, in which he provides a succinct analysis of the application of Ontario's Human Rights Code. Bhabha's scholarship is informed by his own lived experiences as an advocate for the claimant, an adjudicator, a vice-chair for Human Rights Tribunal, and now a law professor. These multiple roles have allowed him to provide us within an 'insider's view' as an expert. Bhabha invokes Patricia Williams' text to illustrate a particular rights approach. He further suggests that "rights can lead to positive outcomes, such as vindication, legitimation and truth-telling with respect to discrimination and its underlying causes. But, the power of rights also can produce negativity and lead to resistance to litigation-driven rights reform." ${ }^{42}$ In highlighting specific judicial decisions to illustrate pervasive unconscious racial bias within a litigation context, Bhabha's intervention can be characterized as providing an analytical framework for critical theory praxis, thereby steering lawyers and activists towards a rights-based litigation agenda. This article raises legal consciousness in its depiction of how human rights litigation is used to maintain, reject or augment the status quo. Its engagement with critical race theory uncovers the "images of power" that are deep seeded into daily narratives of claimants. Bhabha eloquently states "[R]ights claimants experience a sense of power when they reconstruct the images before the law, from stereotype to truth. A successful human rights decision, like Pieters, can do that." In particular, by fusing theoretical debates with the challenges of human rights legislation, this article adds another dimension to Canadian critical race scholarship.

The two short reflections by Williams and Lawrence are based on their comments at the symposium. Williams' remarks during the symposium, using the critical race theory method of storytelling, ${ }^{43}$ sought to interrupt the powerful but naive narrative of law as a tool to reconcile the effects of environmental catastrophes. She deployed the American experiences of Black women in the wake of hurricane Katrina to illustrate the dangers of, and the contradictory nature of liberal legalism. Similarly, in her reflection included in this Special Issue, Williams takes recent media headlines of a suicide in New York City to illustrate the power and dangers in constructing a specific narrative. Lawrence closes the Special Issue by asking what is the significance of trying to re-ignite critical race theory? Moreover Lawrence suggests that Canadians cannot rely on the work of critical race theory in the United States for three specific reasons: context, proof and praxis. The Special Issue includes two personal reflections by Irina Ceric and Reggo Nasser. The pieces appear distinctly juxtaposed to each other; however, they all provide a somewhat transnational perspective using critical race theory as a platform to analyze their

41 Adrian Smith, "Racialized In Justice”, supra note 6.

42 Faisal Bhabha, 'Islands of Empowerment': Anti-Discrimanation Law and the Question of Racial Emancipation"'

[Windsor Yearbook of Access to Justice, Forthcoming in this symposium issue] p 65.

43 Delgado \& Stefancic, supra note 1 at 1-16. 
respective viewpoints as legal activists. Ceric and Nasser situated their reflections in a global context of critical race theory as they chronicle their journey; they both share their own personal rendition of rights and wrongs encountered along the way. These reflections demonstrate a varied model in articulating 'injustice'.

\section{CONCLUSION}

Canada although known for its grand narratives of "racial and cultural tolerance"44 and as a "mecca for the oppressed" has not truly fulfilled that particular vision. ${ }^{45}$ In fact, upon landing at Toronto's Pearson Airport, the visitor is greeted by a beautiful colourful collage of pictures depicting members from diverse communities, with wide smiles and dressed in resplendent cultural clothing. The word "Welcome" in different languages is also displayed on a large mural hanging prior to entering the customs area overseen by Canada Border Services Agency. The initial imagery that is portrayed can be characterized as aspirational, as opposed to actual. Carol Aylward reminds us that "a dichotomy exists between Canada's public and international image as an "egalitarian" society free from the racism that plagues the United States and the actual racial reality in this Country." ${ }^{, 46}$ In this regard, these papers and reflections present an alternative reality of the manner in which race as a social marker occupies our Canadian imagination. Scholars, building on the work of Sharene Razack, Hamini Banerji, Ena Dua, Bonita Lawrence, Sonia Lawrence and others, trace the insidious pathology of how race as category is deployed in our legal system. Much more fundamentally, these scholars represent the diverse voices of critical race scholarship in our globalized settler colonial academic landscape.

Even though interdisciplinary scholars working in these areas take note of the earlier interventions, our current reality is such that critical race scholars work in isolation. They have formed their own isolated communities that only a marginal number of people know of. ${ }^{47}$ In this context, how do scholars bring a critical race theory approach to the forefront? Is it through legal praxis, employing experiential learning? Or, should legal academics use this particular lens to interrogate the methodology and substantive issues raised in other fields of law?

By employing critical race theory as a response to the hegemonic traditions embedded in law, it can be posited as another language that we use to respond to and evaluate power relations. Not only does this approach allow us to depart from normative assumptions, but it allows scholars to use this lens as an

44 Aylward, supra note 39 at 40.

45 Ibid.

46 Ibid.

47 A handful of fields have been more successful in integrating a critical race theory approach in legal scholarship, such as criminal law and international law; see for example David M Tanovich, "The Charter of Whiteness: Twenty-Five Years of Maintaining Racial Injustice in the Canadian Criminal Justice System' (2008) 40 SCLR (2d) 655; David M Tanovich, "Moving Beyond 'Driving While Black': Race, Suspect Description and Selection" (2005) 36 Ottawa L Rev 315; Sujith Xavier, "Theorising Global Governance Inside Out: A Response to Professor Ladeur" (2013) 3 Transnational Legal Theory 268; Amar Bhatia, "The South of the North: Building on Critical Approaches to International Law with Lessons from the Fourth World” (2012) 14:1 Oregon Review of International Law 13; Makau Mutua, "Critical Race Theory and International Law: The View of an Insider-Outsider" (2001) 45 Vill L Rev 84; Antony Anghie \& BS Chimni, "Third World Approaches to International and Individuals Responsibility in Internal Conflicts" (2003) 2:1 Chinese Journal of International Law 711. 
intellectual GPS to navigate and explore alternative modes of thinking. The papers reflected in this Special Issue provide valuable insights on how legal scholars mesh activism with theoretical inclination in showcasing a novel methodology in deciphering realities on the ground.

The thoughtful and deeply personal engagement with Williams' text was the ultimate goal of the initial Call for Papers and the Symposium. The reflection pieces included in this Special Issue may seem unorthodox to the regular readers of the Windsor Yearbook of Access to Justice. But we include them as an extension of how 'narrative' is manifested in legal scholarship. ${ }^{48}$ By reframing the way we design and develop academic literature, we want to empower scholars to utilize their own style, thereby allowing them to deviate from traditional, conservative and orthodox models of scholarly writing as was experienced by reading Williams' text. Story-telling in a "narrative form to demonstrate the effect of social policies on the lived experiences of individuals" 49 has become a methodology used by critical race theory scholars, lawyers and activists.

Historically, this type of a "narrative dimension" appears to have been an effective and persuasive form in providing a glimpse of the effects of racism. This method of "personal revelation", pioneered by the late US Supreme Court Justice Thurgood Marshall as a litigation strategy, allowed the judiciary to employ legal analysis to pragmatic social issues. ${ }^{52}$ The power of story-telling should not be underestimated, as we have attempted to demonstrate in this Special Issue and to draw from scholarship such as The Alchemy of Race and Rights, and integrate that into our respective fields. Challenging the way we think about legal scholarship can have an affect on how we teach. The muted efforts across legal pedagogy that incorporate critical race theory must be transformed.

48 Delgado \& Stefancic, supra note 1at 1-16.

49 Robert L Hayman Jr. \& Nancy Levit, "Un-natural Things: Constructions of Race, Gender and Disability" in Francisco Valdes et al, eds, Crossroads, Directions and A New Critical Race Theory (Philadelphia: Temple University Press, 2002)

$50 \quad$ Ibid at 175 .

51 Ibid.

52 Ibid at 176. 